\title{
CHARITY LAW, THE ADVANCEMENT OF RELIGION AND PUBLIC BENEFIT - WILL THE UNITED KINGDOM BE THE ANSWER TO NEW ZEALAND'S PRAYERS?
}

\author{
Juliet Chevalier-Watts*
}

\begin{abstract}
The law of charity and religion has an ancient relationship and religion, for charity law purposes, recognises a plethora of belief systems. However, for a religion to be recognised at law in New Zealand and in the United Kingdom it must have public benefit, whether that is a presumed requirement or to be shown expressly. This requirement of public benefit has generated much debate over the decades, in parliaments, in courts and in academia. This article considers the very real issues associate with public benefit and the advancement of religion in charity law and asks whether the contemporary approach of the United Kingdom with regard to the removal of the presumption of public benefit would provide a more certain legal path for New Zealand courts and charitable bodies.
\end{abstract}

\section{INTRODUCTION TO RELIGION AND CHARITY}

The contribution of religion and its various organisations to building institutional infrastructures and shaping societies should not be underestimated. ${ }^{1}$ Religion has been said to be at the heart of civil society in England and Wales, ${ }^{2}$ as well as laying many of the foundations of the present health and education systems in Ireland, Australia, New Zealand, Canada and other countries. ${ }^{3}$ Religion can also be said to be of great importance in the legal environment. For instance, it may offer

\footnotetext{
* Juliet Chevalier-Watts, Senior Lecturer in Law, Associate Dean Research, Te Piringa - Faculty of Law, University of Waikato, New Zealand, julietcw@waikato.ac.nz; Editor in Chief, Waikato Law Review.

1 Kerry O'Halloran "Charity and Religion: International charity reform outcomes and the choices for Australia" (2011) 17(2) Third Sector Review 29 at 30.

2 Debra Morris "Charities and the Big Society: a doomed coalition?" (2012) 32 LS 132 at 132.

3 O'Halloran, above n 1, at 30-31.
} 
protection in plural societies to minority or unpopular religious communities that may require particular protection, and it is widely accepted, although not universally, ${ }^{4}$ that religion has a beneficial impact on the community thus religious pursuits should be encouraged by law "since they promote the interests of society". ${ }^{5}$

The history of charity law - including the law pertaining to religion and religious organisations recognised as being charitable at law - is ancient. The earliest reported case relating to charitable purpose dates from $300 \mathrm{AD}$, with some of the earliest charities being recorded as medieval schools, hospitals, almshouses, and the support of the Church. History shows that gifts to religion and religious purposes were only charitable if for the Catholic Church; that was until Henry VIII established the Church of England and then any support for religion or religious purposes falling outside of the newly established Church of England was said to be for superstitious use or illegal. ${ }^{6}$ Clearly, however, society and law has seen a more progressive and tolerant approach to religion, with the acceptance, albeit gradually, of many other religions. Legally recognised religions within a number of Common Law jurisdictions include: Judaism, Hinduism, Buddhism, Scientology, Catholicism and Presbyterianism. ${ }^{7}$ In terms of a purpose being recognised legally as advancing religion, the criteria in Australasia is twofold. First, there must be a belief in a supernatural being, thing or principle, and secondly, there must be an acceptance of canons of conduct that give effect to that belief. ${ }^{8}$ In order to advance a religion, an organisation or purpose must take positive steps to promote or spread the message that will support or sustain the religious message amongst mankind. ${ }^{9}$ The Charity Commission of England and Wales notes that the definition of religion is characterised by: ${ }^{10}$

- the belief in a god (or gods) or goddess (or goddesses), or supreme being, or divine or transcendental being or entity or spiritual principle, which is the object or focus of the religion (referred to in this guidance as "supreme being or entity");

4 Andrew Iwobi "Out with the old, in with the new: religion, charitable status and the Charities Act 2006" (2009) 29 LS 619 at 621.

5 At 621 .

6 Francesca Quint and Peter Hodkin "The Development of Tolerance and Diversity in the Treatment of Religion in Charity Law" (2007) 10(2) CL \& PR 1 at 3.

7 At 4-5.

8 Church of the New Faith v Commissioner of Payroll Tax (1983) 154 CLR 120 at [17].

9 United Grand Lodge of Ancient Free and Accepted Masons of England v Holborn Borough Council [1957] 1 WLR 1080 (CA) at 1090.

10 The Advancement of Religion for the Public Benefit (Charity Commission (UK), December 2011) at Annexe A. 
- the belief system involves a relationship between the believer and the supreme being or entity by showing worship of, reverence for or veneration of the supreme being or entity;

- $\quad$ the belief system has a degree of cogency, cohesion, seriousness and importance;

- $\quad$ the belief system promotes an identifiable positive, beneficial, moral or ethical framework

There must also be an advancement or promotion of the religion. Section 3(2)(a) of the Charities Act 2011 of England and Wales also notes that "religion" includes a belief in more than one god and also no belief in a god. ${ }^{11}$

For Common Law jurisdictions, the law governing the relationship between charity and religion, in essence, finds its roots in the Statute of Charitable Uses Act 1601, or the Statute of Elizabeth, specifically the Preamble, which set out a non-exhaustive list of purposes that were considered charitable. The Statute has long since been repealed. Modern day courts still refer to this Preamble as a method of determining the charitable nature of a purpose. The next important stage in the law governing charity and law, including religion, occurred in the case of Commissioners for Special Purposes of Income Tax v Pemsel, where Lord Mcnaghten infamously set out what have become the four heads of charity: the relief of poverty, the advancement of religion, the advancement of education and any other purposes beneficial to the community. ${ }^{12}$ These heads of charity are captured in New Zealand under s 5 of the Charities Act 2005. As to why advancement of religion is one of the four Pemsel heads, it was explained in Liberty Trust $v$ Charities Commission that, in reference to the Australian case of Roman Catholic Archbishop of Melbourne v Lawlor, it was because the "law has found a public benefit in the promotion of religion as an influence upon human conduct". 13

The Charities Act 2005 (NZ) and the Charities Act 2006 (UK) - the latter now consolidated in the Charities Act 2011 (UK) - provide that an entity will only be charitable if its purposes are charitable. ${ }^{14}$ It is long-established that for any trust to be recognised as legally charitable, it must not only fall within one of the four heads of charity, ${ }^{15}$ it must also satisfy the public benefit test. Where trusts may fall within one or more of the first three heads of charity, it is accepted that the public

11 Charities Act 2011 (UK), s 3(2)(a)(i)-(ii).

12 Commissioners for Special Purposes of Income Tax v Pemsel [1891] AC 531 (HL) at 583.

13 Roman Catholic Archbishop of Melbourne v Lawlor (1934) 51 CLR 1 at 33 as cited in Liberty Trust v Charities Commission [2011] 3 NZLR 68 (HC) at [53]. See generally Juliet Chevalier-Watts Charity Law in New Zealand (Thomson Reuters, Wellington, 2014) at ch 5.

14 Charities Act 2005, s 5; and Charities Act 2011 (UK), s 4

15 The Charities Act 2011 (UK) now recognises 13 heads of charity, with advancement of religion remaining one of these: at s $3(1)(c)$. 
benefit element is presumed, except until recently in England and Wales, ${ }^{16}$ unless that presumption is rebutted. Charitable purposes falling within the fourth head, that of any other purposes beneficial to the community, are not presumed to be for the public benefit, and that benefit must be set out expressly in New Zealand.

Not only is there a lack of a statutory definition of public benefit, but there is also an absence of a straightforward or comprehensive definition in case law. This has led, inevitably perhaps, to varying legal interpretations. ${ }^{17}$ The scope of uncertainty of public benefit and its presumption has been apparent for centuries, and this scope of uncertainty is demonstrated throughout this article, both in United Kingdom and New Zealand. The New Zealand Government agreed to conduct a review of the Charities Act 2005, which included undertaking a review of the charitable purpose definition to be completed by 2015 , but it was recently announced that the review has been postponed. ${ }^{18}$ In light of this postponement, and a future review, this article considers the very real issues associated with the presumption of public benefit and considers whether New Zealand should consider, as part of the future review, whether the United Kingdom's removal of the presumption of public benefit would be the panacea for the New Zealand public benefit ills and, if so, would it be a preferable path for New Zealand to consider in order to provide more legal certainty in relation to the advancement of religion.

This article does not seek to provide an exhaustive list of all the religious purposes cases, instead it evaluates a number of significant cases that illustrate some of the key issues surrounding the presumption of public benefit with regard to the advancement of religion.

\section{PUBLIC BENEFIT}

It would be fair to say that the notion of "public benefit" has "generated lively parliamentary, legal and journalistic debate in recent years, not least in relation to ... the merits or otherwise of religious organisations". ${ }^{19}$ This article will explore just some of these debates in endeavouring to answer the original proposition.

The requirement of public benefit has two overlapping requirements. First, "the persons eligible to participate in the religious purposes must be an inclusive, public group, rather than an exclusive,

16 The Preamble of the Statute of Elizabeth 1601 provided a non-exhaustive list of charitable purposes, which were distilled in to the four heads of charity by Lord McNaghten in Pemsel, above n 12: the relief of poverty, the advancement of education, the advancement of religion and any other purposes beneficial to the community not falling under any preceding head. A presumption of public benefit for all heads of charity was first removed by the Charities Act 2006 (UK).

17 Mary Synge "A State of Flux in Public Benefit Across the UK, Ireland and Europe" (2013) 16 CL \& PR 163 at 164.

18 Jo Goodhew "No review of the Charities Act at this time" (press release, 16 November 2012).

19 Synge, above n 17, at 163. 
private group". ${ }^{20}$ The actual number of persons choosing to take advantage of the purposes is not of concern so long as, in principle, others may join. ${ }^{21}$

The second requirement, which will be the focus of this article, is that the purposes of the religion or organisation must benefit society generally. Prima facie, these requirements appear straightforward, however, in reality: ${ }^{22}$

The concept of public benefit is intangible and nebulous; its effects can only be represented as variable

and unpredictable. Imprecision has resulted in illogical and capricious decisions, sometimes impossible

to reconcile.

Indeed, the notion of this two-limbed test that has been developed by the courts over hundreds of years has not always been referred to consistently. It has sometimes been referred to as "the first and second test alone, depending on which was in issue before the court", ${ }^{23}$ or sometimes a court would refer to charitable status generally, ${ }^{24}$ "or synonymously with purposes of general public utility or, more broadly, with the fourth head of charity". 25

More recently the Upper Tribunal in $R$ (Independent Schools Council) v Charity Commission noted that courts have "adopted an incremental and somewhat ad hoc approach in relation to what benefits the community", ${ }^{26}$ and that there has never been a comprehensive attempt to define that which is of public benefit. However, what the Tribunal did do was discern from the jurisprudence that there are two related aspects of public benefit. The first is that the nature of the purpose must be of benefit to the community. This the Tribunal refers to as "public benefit in the first sense". ${ }^{27}$ This equates to the second requirement of public benefit, to which this article has just referred. The second aspect of public benefit noted by the Tribunal is that "those who may benefit from carrying

20 Pauline Ridge "Religious Charitable Status and Public Benefit in Australia" (2011) 35 MULR 1071 at 1074 referring to Oppenheim v Tobacco Securities Trust Co Ltd [1951] AC 297 (HL).

21 Inland Revenue Commissioners v Baddeley [1955] AC 572, as cited in Ridge, above n 20, at 1074

22 GHL Fridman "Charities and Public Benefit" (1953) 31 Can Bar Rev 537 at 539 as cited in Jean Warburton "Charities and Public Benefit - From Confusion to Light?" (2008) 10(3) CL \& PR at 2.

23 Synge, above n 17, at 165 referring to Oppenheim, above n 20 (citations omitted).

24 Synge, above n 18, at 165 referring to Re Hummeltenberg [1923] 1 Ch 237 at 240.

25 Synge, above n 17, at 165 referring respectively to Townley v Bedwell (1801) 6 Ves Jun 194, 31 ER 1008 and National Anti-Vivisection Society v IRC [1948] AC 31 (HL) at 42 and 47 (citations omitted).

$26 R$ (Independent Schools Council) v Charity Commission [2012] Ch 214 (UT (Tax)) at [44].

27 At [44] 
out of the purpose must be sufficiently numerous" 28 and identifiable as being a section of the public. $^{29}$

Therefore, "'[p]ublic benefit' is a term which deserves to be taken seriously", ${ }^{30}$ and in order to understand the issues associated with public benefit, and in particular the second requirement of public benefit, it is necessary to consider some of the key jurisprudence over the centuries.

In the 18th century case, Jones $v$ Williams, the Lord Chancellor noted that charity was "a gift to a general public use, which extends to the poor as well as to the rich". ${ }^{31}$ The key to the Statute of Elizabeth was that of public benefit, ${ }^{32}$ and whilst there may have been no explicit reference to public benefit prior to the case of Pemsel, this is explained as follows: ${ }^{33}$

The explanation for the dearth of explicit reference to public benefit before Pemsel seems to be that, until the end of the Victorian era, public benefit was implicit in the legal meaning of charity, so that a charitable purpose was necessarily a purpose for public benefit.

Therefore, "a trust, in order to be charitable, must be of [a] public character". ${ }^{34}$ This then suggests that the concept of public benefit has been inherent in charities for centuries ${ }^{35}$ and "indeed explains equity's particular tenderness for charitable trusts". ${ }^{36}$

Interestingly, whilst the advancement of religion is legally recognised as one of the four heads of charity, it may come as some surprise that the Preamble to the Statute of Elizabeth made no explicit reference to the advancement of religion. The closest it came to such a charitable purpose was the repair of churches. ${ }^{37}$ This exclusion can perhaps be explained by understanding the secular

28 At [44].

29 See also Oppenheim, above n 20.

30 Synge, above n 17, at 163.

31 Jones v Williams (1767) Amb 651 at 652, 27 ER 422 at 422 as cited in Michael Gousmett "The History of Charitable Purpose Tax Concessions in New Zealand: Part 1" (2013) 13 NZJTLP 139 at 139.

32 Gousmett, above n 32, at 139 referring to Gareth Jones History of the Law of Charity 1532-1827 (Cambridge University Press, London, 1969) at 27.

33 Peter Luxton "Public benefit and charities: The impact of the Charities Bill on independent schools and private hospitals" (1 March 2006) Lancaster University Law School <www.lancs.ac.uk/fass/law> at 3 as cited in Gousmett, above n 31, at 140.

34 Jean Warburton, Debra Morris and NF Riddle Tudor on Charities (9th ed, Sweet \& Maxwell, London, 2003) at 7 as cited in Gousmett, above n 31, at 139. See also Jones, above n 33, at 22-52.

35 Gousmett, above n 31, at 139 referring to Luxton, above $\mathrm{n} 33$.

36 Luxton, above n 33, as cited in Gousmett, above n 31, at 139.

37 Chevalier-Watts, above n 13, at ch 5 . 
position of the period of Elizabeth I "and the desire of the Puritans to have a religion free of state interference", ${ }^{38}$ although religion and charity have for centuries been closely associated. Nonetheless, that relationship has not been without its issues, and "history reflects the oftentimes difficult and shifting relationship between State and religion". ${ }^{39}$ Therefore religious purposes up until the 19th century "tended to be enforced on [a] distinct and separate jurisdictional basis"40 up until the decisions of firstly, Morice v Bishop of Durham, that tied the definition of charitable purposes to the spirit and intendment of the Preamble, ${ }^{41}$ and then in the later religious case of Cocks $v$ Manners. Vice Chancellor Sir John Wickens noted: ${ }^{42}$

It is said, in some of the cases, that religious purposes are charitable, but that can only be true as to religious services tending directly or indirectly towards the instruction or the edification of the public.

Sir John Wickens did much to entrench the consideration of public benefit and the advancement of religion, when he "took the logical step of applying a public benefit, preamble-based methodology to religious charitable purpose" ${ }^{43}$ This notion of public benefit, and its presumption, has continued to this day, albeit with all its associated controversies, in particular "where the presence of public benefit from religious purposes has been contested, it has proved very difficult to pin down exactly what will constitute the requisite benefit". ${ }^{44}$ It is to the issue of the presumption of public benefit that we now turn.

\section{THE PRESUMPTION OF PUBLIC BENEFIT}

It is, as mentioned earlier, a well-established principle that where a purpose falls under the first three heads of charity, then the court would presume that it would be charitable unless that presumption was rebutted. As a result, it is evident that in a number of cases concerning poverty, education and religion courts simply failed to address the element of public benefit, even if it might have been relevant. ${ }^{45}$ This was exemplified in Attorney-General $v$ The Earl of Lonsdale, where a school for education of the sons of gentlemen was held to be charitable simply because schools of

38 At ch 5 referring to Gino Dal Pont Charity Law in Australia and New Zealand (Oxford University Press, Melbourne, 2000) at 147.

39 Chevalier-Watts, above n 13, at 168 referring to Ann O'Connell and Joyce Chia "The advancement (or retreat?) of religion as a head of charity: A historical perspective" in John Tiley (ed) Studies in the History of Tax Law (Hart Publishing, Portland, 2013) vol 6 at 369.

40 Ridge, above n 20, at 1076.

41 At 1076 referring to Morice v Bishop of Durham (1804) 9 Ves Jun 399 at 405.

42 Cocks v Manners (1871) LR 12 Eq 574 (Ch) at 585 as cited in Ridge, above n 20, at 1076.

43 Ridge, above n 20, at 1077.

44 At 1077.

45 Warburton, above n 22, at 4. 
learning were charitable. ${ }^{46} \mathrm{~A}$ further example is to be found in Re Watson, where a trust to publish and distribute works of a religious character were found to be charitable even though "there was evidence that the intrinsic value of the works was nil". ${ }^{4}$

As a result therefore, the notion of the presumption of public benefit, and specifically in relation to the advancement of religion, has been fraught with difficulties and inconsistencies. Some of these difficulties stem from courts having to make a value judgement on whether the purpose in question provides a benefit or a harm to society. Such judgements will undoubtedly be influenced by the social values of the time, although courts have stated that an objective, as opposed to a subjective approach should be taken when determining the issue of public benefit. ${ }^{48}$

Indeed, as Warburton notes, it is not difficult to find instances where individual judicial views "intrude into the assessment of the evidence". ${ }^{49}$ For instance, in National Anti-Vivisection Society, Lord Wright stated: 50

Harvey was only able to publish in 1628 his great work De motu cordis because he had been given deer

from the Royal Park for purposes of vivisection. Countless millions have benefited from that discovery.

I do not minimise the sufferings of the unfortunate deer.

Harman LJ in the case of Re Pinion was clearly imposing his own view when he stated, rather forcefully: "I can conceive of no useful object to be served by foisting upon the public this mass of junk." ${ }^{11}$ It is accepted that Re Pinion concerned the advancement of education, but it is submitted that this is a useful example of the principle of public benefit and subjective judicial views.

The recent English case of $R$ (Independent Schools Council) $v$ Charity Commission offers a contemporary exploration of public benefit and its alleged presumption, and asserts that the presumption of public benefit actually may never have existed. ${ }^{52}$ It is acknowledged that this is a very lengthy case, and for the purposes of this article, I will concentrate on addressing public benefit

46 At 4 referring to Attorney-General v The Earl of Lonsdale (1827) 1 Sim 105 (Ch). See also Brighton College v Marriott [1926] AC 192 (HL) at 204.

47 Warburton, above n 22, at 4 referring to Re Watson [1973] 1 WLR 1472 (Ch). See also Peter M Smith "Religious Charities and the Charities Act 2006" (2007) 9(3) CL \& PR 57.

48 Warburton, above n 22, at 5-7 referring to Re Hummeltenberg, above n 24, at 242; National AntiVivisection Society, above n 25, at 44; and Gilmourv Coats [1949] AC 426 (HL) at 456.

49 Warburton, above n 22, at 5.

50 National Anti-Vivisection Society, above n 25, at 48, as cited in Warburton, above n 22, at 5.

51 Re Pinion [1965] Ch 85 at 107, as cited in Warburton, above n 22, at 5.

$52 R$ (Independent Schools Council) v Charity Commission, above n 26. 
in the second sense, as referred to earlier; in other words, that "the nature of the purpose itself must be such as to be a benefit to the community". 53

In relation to the issue of the non-existence of the presumption of public benefit, the Tribunal in $R$ (Independent Schools Council) $v$ Charity Commission referred to, inter alia, the dictum of Lord Wright in National Anti-Vivisection Society. ${ }^{54}$ In the Tribunal's view with regard to the notion of the presumption of public benefit (in the second sense to which this article refers, although the Tribunal refers to it as the first sense) it was not until the decision of National Anti-Vivisection Society that there was any judicial statement that might be construed as referring to the presumption of public benefit, and even that case did not use the word "presumption" explicitly. Lord Wright, in the National Anti-Vivisection Society case noted: ${ }^{55}$

The test of benefit to the community goes through the whole of Lord Macnaghten's classification, though as regards the first three heads, it may be prima facie assumed unless the contrary appears.

The Tribunal was of the view that Lord Wright's approach was consistent with his learned colleague Lord Simonds, in the same case, where Lord Simonds stated: ${ }^{56}$

I would rather say that, when a purpose appears broadly to fall within one of the familiar categories of charity, the court will assume it to be for the benefit of the community and, therefore, charitable, unless the contrary is shown, and further that the court will not be astute in such a case to defeat on doubtful evidence the avowed benevolent intention of a donor. But, my Lords, the next step is one that I cannot take. Where on the evidence before it the court concludes that, however well-intentioned the donor, the achievement of his object will be greatly to the public disadvantage, there can be no justification for saying that it is a charitable object. If and so far as there is any judicial decision to the contrary, it must, in my opinion, be regarded as inconsistent with principle and be overruled. This proposition is clearly stated by Russell J in In re Hummeltenberg, "In my opinion," he said, "the question whether a gift is or may be operative for the public benefit is a question to be answered by the court by forming an opinion upon the evidence before it."

Therefore, the Tribunal concluded that a court, instead of making a presumption as to public benefit, will form its own view "on the evidence before it whether the trust is for the public benefit". ${ }^{57}$ It will do so, not by way of making an assumption, but rather by way of decision. ${ }^{58}$ In

53 At [44].

54 National Anti-Vivisection Society, above n 25.

55 (Independent Schools Council), above n 26, at [62] citing in part National Anti-Vivisection Society, above $\mathrm{n} 25$, at 42 .

56 National Anti-Vivisection Society, above n 25, at 65-66 as cited in $R$ (Independent Schools Council), above n 26, at [64]. See also Re Hummeltenberg, above n 24, at 242.

$57 R$ (Independent Schools Council) v Charity Commission, above n 26. 
other words, this approach is far from a presumption of public benefit in the usual sense, and as far as the Tribunal was aware, "the courts have never made any assumption about whether a purpose is directed to the public or a sufficient section of the public". ${ }^{59}$ Instead, a judge would determine the public benefit because the evidence before them is sufficient, in the "absence of any contrary evidence", 60 to establish such a benefit. ${ }^{61}$

Case law illustrates, therefore, that the notion of the presumption of public benefit generally has raised many issues over the years. For the purposes of this article, a number of cases will be considered that highlight the alleged judicial inconsistencies with regard to this doctrine in relation to religion and public benefit. Starting with English law, and then turning to New Zealand law, clear differences in application can be seen, differences that have been subject to criticism. As a result of such criticisms, the article then considers how the contemporary approach of the United Kingdom since the removal of the presumption of public benefit may provide a more consistent judicial approach in New Zealand.

\section{EARLY ASSOCIATIONS BETWEEN RELIGION AND PUBLIC BENEFIT}

The notion of the presumption of public benefit, or its equivalent, appears to have been present in the common law for centuries, albeit not always in a manner that is explicit. It was evident that courts associated religion and charities as comfortable bed fellows, but there was no outward consideration in those early cases that the public would benefit from the purposes in question. ${ }^{62}$ For example, in the case of Attorney-General v Baxter, Sir Francis North struck down a trust for superstitious use, although he did say that there was charitable intention, and so should fall under the doctrine of cy-près. ${ }^{63}$ Harding argues that Baxter turned on two principles: first, that the superstitious use had to be struck down as being void; but secondly, that a trust for religious purposes was a charitable purpose. Therefore a trust for charitable purposes should be recognised as

58 At [68].

59 At [69]. See also Attorney-General $v$ The Charity Commission for England and Wales UTTCC FTC/84/2011, 20 February 2012.

$60 R$ (Independent Schools Council), above n 26, at [69].

61 At [69].

62 Matthew Harding "Trusts for Religious Purposes and the Question of Public Benefit" (2008) 71 MLR 159 at 161.

63 The equitable doctrine of cy-près permits a charitable trust to be modified in appropriate circumstances. It permits funds in a charitable trust, "where the intended purpose of the trust had become impossible or impracticable, to be applied by the Court to objects that were as near as possible to the original intention of the donor." See Chevalier-Watts, above n 13, at ch 8 referring to St John of the God Health \& Elder Care Services Trust Board v Little Sisters of the Poor (NZ) Trust Board HC Napier CIV-2007-441-628, 11 August 2008 at [20]. 
far at the law permits. ${ }^{64}$ As a result "[t]he natural association of religion and charity meant that whether the public would benefit from the maintenance of non-conformist clergymen was simply not considered". ${ }^{65}$ This suggests then that it was the natural association of religion and charity that enabled the trust to be regarded as charitable. ${ }^{66}$

Another example given by Harding is that of Da Costa $v \mathrm{Da} P a z$, where the testator bequeathed some money for the support of Jesuba to instruct youth in the Jewish religion. This trust was also struck down for superstitious use, but it was argued that Lord Harwick would not have struck it down if Judaism had been tolerated in English law at the time. ${ }^{67}$ Thus this view is "best understood as resting on a natural association of religion and charity". 68

Whilst it is submitted that these early examples do not demonstrate any presumption of public benefit, the natural association of charity and religion actually performs a similar role to that of the presumption in contemporary cases. ${ }^{69}$ This enabled courts to recognise religious purposes as charitable without "requiring evidence on the basis of which such a favourable view might be justified". 70

So in more modern times, with regard to the advancement of religion, any religion has invariably been presumed to be inherently beneficial because "any religion is at least likely to be better than none". ${ }^{71}$ Therefore the suggestion being that the presumption of public benefit was likely only to be rebutted in extreme circumstances where the beliefs or doctrines of the said religion would be "adverse to the very foundations of all religion, and that they are subversive of all morality". ${ }^{72}$ Indeed the case of Thornton $v$ Howe reflects this judicial affirmation of religious tolerance. ${ }^{73}$

64 Harding, above n 62, at 161.

65 At 161

66 At 161; and Juliet Chevalier-Watts "Trusts for Religious Purposes: Earthly Tests and Ethereal Matters" [2010] NZLJ 55 at 56.

67 Harding, above n 62, at 161-162 referring to Da Costa v Da Paz (1754) 1 Dickens 259, 21 ER 268.

68 At 162. See also Cary v Abbott (1802) 7 Ves Jun 490

69 Harding, above n 62, at 161-162; and Chevalier-Watts, above n 66, at 56.

70 Harding, above n 62, at 163.

71 Neville Estates v Madden [1962] Ch 832 at 853 as cited in Smith, above n 47, at 63.

72 Thornton $v$ Howe (1862) 31 Beavan $14(\mathrm{Ch})$ at 20, 54 ER 1042 at 1044 as cited in Smith, above n 47, at 63 and approved in Re Watson, above $\mathrm{n} 47$, at 1478-1479.

73 Hubert Picarda "Thornton v Howe: A Sound Principle or a Seminal Case past its best buy date?" (2013) 16 CL \& PR 91. 
The case of Thornton concerned the printing and propagating of the sacred writings of Joanna Southcote, who: ${ }^{74}$

... laboured under the delusion that she was to be made the medium of the miraculous birth of a child at

an advanced period of her life, and that thereby the advancement of the Christian religion on earth would be occasioned.

The plaintiff claimed that these beliefs were blasphemous or profane in character. ${ }^{75} \mathrm{Sir}$ John Romilly MR, believed that "she was a foolish, ignorant woman, of an enthusiastic turn of mind, who had long wished to become an instrument in the hands of God to promote some great good on earth", ${ }^{76}$ however there was nothing in her writings that "could shake the faith of any sincere Christian". ${ }^{77}$ Her writings were largely "incoherent and confused", ${ }^{78}$ but they were clearly written with "a view to extend the influence of Christianity". ${ }^{79}$ This case might be an example of judicial affirmation of religious tolerance, and it certainly falls within the notion that a religious trust should only be rebutted in extreme circumstances where the beliefs or doctrines of the said religion would be "adverse to the very foundations of all religion, and that they are subversive of all morality". ${ }^{80}$ However, it has also been said of this case that it has been "held up as setting the bar extremely low in determining whether a charity is for the advancement of religion". ${ }^{81}$ Further, there is argument that the presumption of public benefit determined the outcome of this case because it would appear that the evidence actually weighed against making a finding of public benefit. ${ }^{82}$ Indeed it appears to be difficult to reconcile such a decision in the absence of the presumption when the Court was able to find "as a matter of fact, that the public would benefit by the dissemination of beliefs" with so little foundation. ${ }^{83}$ However, because there was no explicit mention of public benefit in this case, it is "ultimately a matter of supposition whether or not such a presumption was applied". ${ }^{84}$

74 Thornton $v$ Howe, above $\mathrm{n} 72$, at 20.

75 At 15 .

76 At 18.

77 At 20.

78 At 20 .

79 At 21 .

80 At 20, as cited in Smith, above n 47, at 63 and approved in Re Watson, above n 72.

81 Picarda, above n 73, at 91.

82 Harding, above n 62, at 165.

83 At 165.

84 At 165 . 
This early judicial exploration in to the advancement of religion highlights the issues of finding a religious purpose charitable when the evidence points to the contrary, and certainly Sir John Romilly's "tolerant stance of legal neutrality towards religion has been questioned" because he did not expressly require that the trust convey any public benefit. ${ }^{85}$ Nonetheless, it could be argued that the presumption of public benefit obviated the need to "base findings of public benefit on evidence presented to the court". 86

However, the general inconsistencies of the consideration of the presumption of public benefit are highlighted in case of Cocks $v$ Manners, heard but a few short years after Thornton. ${ }^{87}$ It does appear to reflect the notion that Thornton did perhaps set the bar extremely low regarding the advancement of religion and if the presumption of public benefit was a matter of supposition in Thornton, then it certainly was not in Cocks.

In this case, the testatrix left a gift to an institution consisting of Roman Catholic women living together by mutual agreement in a state of celibacy for the purposes of sanctifying their own souls through prayer and pious contemplation. Sir John Wickens stated: ${ }^{88}$

It is said, in some of the cases, that religious purposes are charitable, but that can only be true as to religious services tending directly or indirectly towards the instruction or the edification of the public.

This is directly in contrast with that of the Court in Thornton where no mention of the presumption of public benefit was made, and indeed, his Lordship asserted that: ${ }^{89}$

... an annuity to an individual, so long as he spent his time in retirement and constant devotion, would not be charitable, nor would a gift to ten persons, so long as they lived together in retirement and performed acts of devotion, be charitable.

Therefore, his Lordship concluded that: ${ }^{90}$

A voluntary association of women for the purpose of working out their own salvation by religious exercises and self-denial seems to me to have none of the requisites of a charitable institution, whether the word "charitable" is used in its popular sense or in its legal sense.

85 Pauline Ridge "Legal Neutrality, Public Benefit and Religious Charitable Purposes: Making Sense of Thornton v Howe" (2010) 31 JLH 177 at 199.

86 Harding, above n 62, at 166.

87 Cocks v Manners, above n 42.

88 At 585

89 At 585

$90 \quad$ At 585 
As a result, his Lordship stated that the gift to the convent was not charitable. ${ }^{91}$ There was no evidence however that this gift was "adverse to the very foundations of all religion, and that [it] was subversive of all morality", 92 which reflects the disparity of the utilisation of the presumption to find public benefit, especially when the decisions were so close to each other in terms of time. However, it is not suggested that either were wrongly decided. Legal neutrality, as exemplified in Thornton, may have merely been a reflection of earlier legislative endorsement of religious tolerance, holding that religious purposes were generally charitable. If that is so, then Cocks could simply be a reflection of the growing realisation that not all religious purposes are charitable, ${ }^{93}$ therefore the utilisation of the presumption of public benefit was a tool to evaluate more stringently such purposes. Whilst however Cocks may then have been a watershed in the jurisprudence of religious purposes and public benefit, and may be reconcilable with Thornton, this argument is not entirely clear cut, and indeed, the case of Hobbs $v$ Smith (Watson) has added fuel to the fire that the presumption of public benefit is rather an unwieldy judicial tool. ${ }^{94}$

In this case, the testatrix made provision for the publication and public dissemination of the religious writings of HG Hobbs. Evidence by an expert was presented to the Court that these writings were of nil intrinsic worth and would not extend the knowledge of Christian religion. However, Plowman J concluded that Thornton provided the relevant approach. In other words, a court should not draw a distinction between one religion and another, and thus the only way of disproving a public benefit is to show that the doctrines are "adverse to the very foundations of all religion, and that they are subversive of all morality". ${ }^{95}$ Therefore the evidence presented to Plowman J did not rebut the presumption of public benefit, even though the expert stated that there was no value to the writings and they would not extend the Christian religion! Thus Thornton and Watson suggest that the presumption of public benefit will only be rebutted in extreme circumstances but Cocks does not appear to present such an extreme circumstance, and neither does the later case of Gilmour $v$ Coats, where again a gift to cloistered nuns was rejected as being charitable because the public benefit was not found. ${ }^{96}$ Thus whilst the presumption of public benefit has been historically easy to express, its application has not necessarily been historically consistent in England and Wales.

91 At 585 .

92 Thornton $v$ Howe, above $\mathrm{n} 72$, at 20.

93 Ridge, above n 85, at 201.

94 Hobbs $v$ Smith [1973] 1 WLR 1472 (Ch).

95 Thorton $v$ Howe, above n 72, at 20 as cited in Hobbs $v$ Smith, above n 94, at 1478-1483.

96 Gilmourv Coats, above n 48. 
Of course, New Zealand's case law has much in common with the United Kingdom and like its commonwealth cousin, New Zealand also appears to reflect inconsistencies with the application of the presumption of public benefit.

\section{NEW ZEALAND AND THE PRESUMPTION OF PUBLIC BENEFIT}

In the case of Presbyterian Church of New Zealand Beneficiary Fund $v$ Commissioner of Inland Revenue, the Presbyterian Church created a fund for the benefit of retired ministers, with the primary benefit of the fund being an annuity payable to retiring ministers. ${ }^{97}$ The Court had to determine whether there was sufficient public benefit for this fund to be charitable. Interestingly, the Court did not refer to the presumption of public benefit, even though it is firmly established under this head of charity, because the public benefit is "presumed unless there are grounds for holding otherwise". ${ }^{98}$ This immediately reflects an inequality of the recognition of this principle, and it suggests that the presumption of public benefit, at least in this case, was not recognised, which is curious.

However, whilst the Court did not explicitly refer to this presumption, it did address the matter of public benefit, and asserted that the fund's objectives were to protect its ministers. In other words, the fund would provide them with sufficient income throughout their life "in accordance with the mutual commitment of Church and minister to a lifelong undertaking". 99 Therefore it was this close connection between the Church, the fund and its ministers that demonstrated the requisite public benefit because "where the overall purpose goes to the benefit of persons who are demonstrably part of the structural workings of the Church overall", the public benefit is clear. ${ }^{100}$

Heron $J$ was of the view that the private benefits to members who received the fund were for the charitable purpose; in other words, the fund was essentially charitably altruistic in purpose,${ }^{101}$ thus the private benefits were ancillary to the public benefits. The justification for this finding was that the retired ministers who received the benefit of the fund were "an integral part of the structure and workings of the Church and without them the Church would cease to exist". ${ }^{102}$ In addition,

97 Presbyterian Church of New Zealand Beneficiary Fund v Commissioner of Inland Revenue [1994] 3 NZLR 363 (HC)

98 Susan Barker "The presumption of charitability" [2012] NZLJ 295 at 295.

99 Presbyterian Church of New Zealand, above n 97, at 371.

100 At 371. See also Juliet Chevalier-Watts "Charitable Trusts and Advancement of Religion: on a Whim and a Prayer?" (2012) 43 VUWLR 403 at 420.

101 Presbyterian Church of New Zealand, above n 97, at 371.

102 At 372 
ministers would not have been induced to take up their calling without the assurance of such financial security.

This case therefore demonstrates that whilst it is established law that presumption of public benefit exists in New Zealand law, a court may still not explicitly recognise its applicability, although even without its acknowledgement, a court can still find that the public benefit is expressed sufficiently. This is evident even in controversial circumstances such as the instant case where, at first sight, it appears that beneficiaries receive generous private benefits. Indeed, the New Zealand Court of Appeal in Hester v Commissioner of Inland Revenue believed that Presbyterian Church was "at the outermost limits of this doctrine". 103

As with the Presbyterian Church, the Court in Hester also did not acknowledge the presumption of public benefit, even though in the context of the advancement of religion, it should be presumed. ${ }^{104}$ The Court of Appeal in Hester had to determine whether a superannuation plan that provided benefits for employees of the Church of Latter Day Saints was for a charitable purpose and therefore income tax exempt. The Court referred at length to the Presbyterian Church case, but in the end determined that whilst superannuation type schemes had a dominant purpose of providing for ministers and their families and thus had charitable purpose, the scheme in Hester was "well beyond the existing doctrine for an allowable charitable trust" because it was too broadly conceived as to those who may come within it. ${ }^{105}$ In other words, it may be possible for gardeners, clerical workers or cafeteria workers who work within the Temple building to come within the rubric, and that, in Hammond J's view "simply goes too far". 106

Whilst the New Zealand courts in Presbyterian Church and Hester may not have acknowledged the presumption of public benefit in relation to the advancement of religion, even though it is an established principle, the opposite can be said to be true for the recent case of Liberty Trust $v$ Charities Commission. ${ }^{107}$ Liberty Trust was registered as a charitable entity in 2007 under the New Zealand Charities Act 2005. Its main activity is to act as a mortgage lending scheme, making interest free loans to donors and other people. The scheme is funded mainly by donations. Its lending scheme prompted the Charities Commission (now the Department of Internal Affairs -

103 Hester v Commissioner of Inland Revenue [2005] 2 NZLR 172 (CA) at [11].

104 Liberty Trust, above n 13, at [99].

105 Hester, above n 103, at [14].

106 At [14].

107 Liberty Trust, above n 13. 
Charities) ${ }^{108}$ to remove the Trust from the Charities Register, which let to Liberty Trust appealing the decision to the High Court.

The organisation stated that its lending scheme advanced religion by demonstrating practical financial lessons derived from the Bible. The Charities Commission, however, stated that "teaching financial principles derived from the Bible was at best conducive to religion but did not advance religion". ${ }^{109}$ The Commission asserted, inter alia, "that the Trust's emphasis was not on propagating the Christian doctrine, but rather on educating people through biblical financial principles, which included savings, spending and charitable giving". ${ }^{110}$ As a result, this would preclude the Trust from falling under the definition of "advancing religion". ${ }^{111}$ In asserting this, the Commission relied on Roman Catholic Archbishop of Melbourne v Lawlor as authority "for the proposition that teaching biblical financial principles would merely be conducive to religion as opposed to actually advancing religion". 112

The main issue in Lawlor was whether the establishment of a Catholic newspaper could advance religion for charitable purposes. The Court acknowledged that, for it to be a newspaper, it obviously would contain "news" and this is likely to be secular in nature, but questioned whether: ${ }^{113}$

... the Catholic Church [would] be any the less engaged in disseminating its religious doctrines and teachings merely because it chose to reach the public by supplying daily information and news, the main object throughout being the propagation of the faith?

Returning then to the Liberty Trust case, Mallon J preferred the approach of the three judges in Lawlor, Gavan Duffy CJ, Evatt and McTiernan JJ, who adopted a broad view of how religion may be advanced. Gavan Duffy CJ and Evatt J noted that they were: ${ }^{114}$

... quite unable to see the difference between the Catholic Church's propagating its religious tenets and regulating the performance of religious duties (1) through a medium reaching into the homes of the multitude, including Catholics and non-Catholics, and (2) through the ordinary medium of sermons and tracts. The former may be as much a method of preaching the gospel as the more direct and obvious method of strengthening or extending faith through missions and sermons.

108 The Charities Commission of New Zealand was abolished in 2012 and its regulatory functions transferred to the Department of Internal Affairs - Charities.

109 Liberty Trust, above n 13, at [2].

110 Chevalier-Watts, above n 100, at 410 .

111 Liberty Trust, above n 13, at [65].

112 Chevalier-Watts, above n 100, at 410. See also Lawlor, above n 13.

113 Lawlor, above n 13, at 16. See also Chevalier-Watts, above n 100, at 410-411.

114 Lawlor, above n 13, at 16. See also Chevalier-Watts, above n 100, at 411-412. 
It is submitted that this is certainly the correct approach to take "because it acknowledges the advancements in society regarding religious instruction and its dissemination". 115 "It is not such a great step to recognise that religion may be advanced through a religious newspaper, so long as the dominant purpose of that newspaper is to instruct those of that religion in 'matters of faith and morals and of advancing and spreading the faith and teachings"'. ${ }^{116}$

In addition, Liberty Trust teaches budgeting and financial matters as part of the "Word of God" so even though secular information is being disseminated, the organisation maintains the religious doctrines upon which the teachings rest, and promotes and manifests those tenets. ${ }^{117}$ "Therefore the biblical financial principles as taught by the Liberty Trust 'are an aspect of Christian Faith as expounded by Liberty Trust."' 118 Whilst this case strengthens the position that religious organisations may undertake secular activities so long as in doing so they pursue an outworking of their religion, it goes further. It also highlights that the further the secular activities are from religion, the more difficult it is to sustain the idea that the organisation is pursuing religious purposes, ${ }^{119}$ which then may rebut the presumption of public benefit.

Mallon J affirmed that applicability of the presumption of public benefit in New Zealand in the Liberty Trust case. This means that: ${ }^{120}$

\footnotetext{
Although the starting point is this presumption/assumption, it remains for the court to be satisfied that the gift satisfies the public benefit requirement. Tudor says that it "is considered that the presumption will be rebutted, and the public benefit will have to be shown positively, if there is evidence that the purpose is subversive of all morality, or it is a new belief system, or if there has been public concern expressed about the organisation carrying out the particular purpose, or if it is focused too narrowly on its adherents.
}

Therefore it is still possible for a Court to be dissuaded of an organisation's public benefit. Mallon J provided an extension of Thorton's method of rebutting the public benefit, which reflects a broadening of the Court's jurisdiction to determine this benefit. However, whilst this prima facie suggests that rebutting the presumption may occur in a greater number of situations than first

115 Chevalier-Watts, above n 100, at 412 .

116 Lawlor, above n 13, at 15 as cited in Chevalier-Watts, above n 101, at 412.

117 Chevalier-Watts, above n 100, at 412 .

118 Liberty Trust, above n 13, at [69] as cited in Chevalier-Watts, above n 101, at 412.

119 Kerry O'Halloran Religion, Charity and Human Rights (Cambridge University Press, Cambridge, 2014) at 447.

120 Warburton, Morris and Riddle, above n 34, at [2-052], as cited in Liberty Trust v Charities Commission, above $\mathrm{n}$ 13, at [100] (closed quotation marks missing in original text of judgment). 
expressed or conceived in Thornton, the reality in Liberty Trust is that, in New Zealand at least, public benefit may be construed very broadly indeed.

Mallon $\mathbf{J}$ affirmed that because she had found that the purposes of the trust advanced religion, then the presumption in the instant case was to assume that the public benefit was conferred, and that this assumption would not be displaced merely because a court may have a different view of the social utility of the scheme. The scheme was not proven to be contrary to public policy, nor was it contrary to any Christian or Biblical principles. ${ }^{121}$ However, it is submitted that the scheme did fall foul of Tudor's proposition that the presumption may be rebutted if the purpose were to be "focused too narrowly on its adherents". ${ }^{122}$

The Charities Commission argued that the private benefits afforded to recipients of the lending scheme to pay off long term debts so that "they can be free to fulfil God's call upon their lives" outweighed the purported public benefits. ${ }^{123}$ In response, Mallon J stated: ${ }^{124}$

\footnotetext{
Liberty Trust is not merely a lending scheme set up to provide private benefits to its members.

Membership is not restricted - it is open to all regardless of faith. For those who join, it is in part intended to provide private benefits, namely to assist with house ownership free of the shackles of interest incurring debt ... but those private benefits are seen as part of living as a Christian. An integral part of the scheme is that its benefits are to be shared with others.
}

Therefore it was asserted categorically that "private benefit is part and parcel of Christian living". ${ }^{125}$ This may be so, "but beyond that there must be an overall purpose of public benefit: the private benefit should be ancillary to the public benefit". ${ }^{126}$ Liberty Trust desired that loanees should be able to live debt free so that they could fulfil God's call, although it is not determined how this should be achieved, and whilst this is commendable, it is merely a hope, "and case law is clear that a mere hope does not equate to a charitable purpose". ${ }^{127}$

Mallon J did note that she found it "difficult to distinguish [the scheme] from a mass in a Church which is open to the public", ${ }^{128}$ but it is respectfully submitted "that a mortgage scheme established

121 Liberty Trust, above n 13, at [100]-[101].

122 Warburton, Morris and Riddle, above n 34, at [2-052].

123 Liberty Trust, above n 13, at [9].

124 At [113].

125 At [121].

126 Chevalier-Watts, above n 100, at 419.

127 Chevalier-Watts, above n 100, at 419 referring to Canterbury Development Corp v Charities Commission [2010] 2 NZLR 707 (HC).

128 Liberty Trust, above n 13, at [122]. 
to relieve private financial impecuniosities with a connection to the Christian faith may be distinguished from public prayers whose prime purpose is to propagate the Christian faith, because the benefits of the loan scheme are too narrowly focused on its adherents". ${ }^{129}$ In other words, to repeat the words expressed in Tudor, it "is considered that the presumption will be rebutted ... if it is focused too narrowly on its adherents". 130

As was so eloquently stated by her Honour, the scheme was about being able to "lead a Christian life free of the burdens of debt". ${ }^{131}$ Surely this primarily supports the notion of private benefit, and is thus "focused too narrowly on its adherents". This being so, the presumption of public benefit should then be rebutted. However, this was not what the Court determined, and instead, Mallon $\mathbf{J}$ found that the lending scheme was a religious one, albeit a scheme that offered private benefits. ${ }^{132}$ As O'Halloran states: ${ }^{133}$

Arguably there is a line to be drawn between the outworkings of a religious faith that, being ancillary and incidental in nature, can be seen to manifest an organisation's religious beliefs, and those that are disproportionate and unrelated to such an organisation and its beliefs.

I respectfully assert that that line has been crossed in the Liberty Trust case where I would argue that the purpose of the scheme is to relieve financial burdens with a hope that the principles of the Christian faith are to be expounded as a result of that relief. ${ }^{134}$ The focus is on the adherents first and foremost, which should theoretically rebut the presumption of public benefit because it appears too remote.

Case law in New Zealand therefore, much like case law in England and Wales, reflects a level of uncertainty in relation to the presumption of public benefit. Whilst the contemporary case of Liberty Trust does indeed affirm the presumption itself, its conclusions may be subject to some criticism, ${ }^{135}$ and suggests that the presumption itself is not rebuttable even when evidence is presented that arguably should rebut the presumption, and perhaps even that it is not "readily evident what evidence will rebut that presumption". ${ }^{136}$

129 Chevalier-Watts, above n 100, at 419.

130 Warburton, Morris and Riddle, above n 34, at [2-052].

131 Liberty Trust, above n 13, at [125].

132 At [113].

133 O'Halloran, above n 119, at 447.

134 Chevalier-Watts, above n 100, at 420.

135 Donald Poirier Charity Law in New Zealand (Department of Internal Affairs, Wellington, 2013) at 141; and Hester $v$ Commissioner of Inland Revenue, above $\mathrm{n} 104$.

136 Donovan Waters "The advancement of religion in a pluralist society (Part II): abolishing the public benefit element" (2011) 17 Trusts \& Trustees 729 at 731. 
What then is the answer for New Zealand with regard to these difficulties? Perhaps the answer may be found in the United Kingdom's statutory removal of the presumption of public benefit as per the Charities Act 2011 (UK).

\section{REMOVING THE PRESUMPTION OF ADVANCEMENT - THE ANSWER TO OUR PRAYERS?}

The Charities Act 2006 (UK) received Royal Assent in November 2006 and came fully into force in April 2008. Its main thrust was to increase the powers of the Charity Commission to protect charities and the duties of the charities to account to the public. The new Act also removed the presumption of public benefit, meaning that all charities, new and existing, will have to satisfy the public benefit test. ${ }^{137}$ The Charities Act 2011 (UK) came into effect on 14 March 2012 and consolidated the 2006 Act. Therefore religious groups or purposes will have to establish on their own specific merits that they do confer a public benefit, meaning that the following is no longer applicable: "the advancement of religion in a general sense is inherently beneficial because English law 'assumes that it is good for man to have and practice a religion"'. 138

The idea of the removal of the presumption was to introduce "a uniform and consistent approach to the operation of the public benefit requirement across all the heads of charity". ${ }^{139}$ The Charity Commission stated that organisations should now demonstrate "factual and positive evidence" of such public benefit in the way in which its purposes are carried out. ${ }^{140}$ This, prima facie, sounds like a logical step, because, as this article has already demonstrated, the presumption of public benefit is inconsistently addressed or even applied. However, the consequences of removing such a presumption may be far reaching, and as a result, may not be the panacea that New Zealand might seek. For instance: ${ }^{141}$

$\ldots$ it becomes necessary to question whether the provision does, in fact, change the law ... or whether it merely affirms the previous case law. If it is the case either that no presumption did exist or that it was not applied previously, then precedent should be unaffected. Even if a presumption did exist and was applied, it might still be argued that the provision did not change the law of evidence, so that the court's ability and willingness to make assumptions and to make findings of fact without inquiry is unaffected.

137 EH Burn and GJ Virgo Maudseley \& Burn's Trusts and Trustees Cases \& Materials (7th ed, Oxford University Press, Oxford, 2008) at 415-419; Charities Act 2006 (UK), s 3(2); and Charities Act 2011 (UK), s $4(2)$.

138 Smith, above n 47 , at 62 .

139 Iwobi, above $\mathrm{n} 4$, at 639 .

140 Analysis of the law underpinning Charities and Public Benefit (Charity Commission (UK), December 2008) at [2.4] as cited in Synge, above n 17, at 171.

141 Synge, above n 17, at 172 (citations omitted). 
Certainly evidence does point to the presumption existing, but as this article demonstrates, a court's ability to test that presumption, or even acknowledge it, can lead to anomalous results, therefore its removal may lead to equally anomalous results.

The Charity Commission has published guidelines regarding public benefit but these guidelines do not overcome difficulties associated with establishing the public benefit of intangible benefits such as spiritual enlightenment and development, which inevitably are closely associated with religion. Spiritual benefits, by their very nature, are not quantifiable nor measurable in any meaningful way, therefore "spiritual benefit, though it is central to a religion's belief that such a benefit accrues to society, remains an enigmatic factor". ${ }^{142}$ How then shall the Charity Commission in England and Wales judge the public benefit from spiritual endeavours?

Moral improvement cases have found favour with the courts in the past, for instance, in the case of Re Wedgewood, ${ }^{143}$ which concerned a facility to slaughter animals, and was found to be charitable because this gift "tends to promote public morality by checking the innate tendency to cruelty". ${ }^{144}$ This approach might then be utilised by the courts to determine intangible moral improvements in society through religious purposes, but Harding argues that moral improvement cases have not been firmly established in case law, ${ }^{145}$ and further, it is arguable that moral improvement cases may rest on the assumption that many people would accept that carrying out such a purpose would bring about moral improvement. ${ }^{146}$ There is no evidence to suggest that most people would accept the proposition that a purpose might improve morals, and lack of evidence does not make that assumption correct. Indeed, Harding asserts that in the moral improvement cases, the courts have not had the benefit of such evidence. So to make such an assumption is actually to apply a presumption of public benefit, which the United Kingdom cannot now do. ${ }^{147}$ Therefore: ${ }^{148}$

... such an assumption seems singularly inappropriate in a modern case on a trust for religious purposes; in a community characterised by religious diversity, it cannot be assumed that most people accept any given proposition about the intangible public benefit that will flow from carrying out a religious purpose.

142 Waters, above n 136 , at 734.

143 Re Wedgewood [1915] 1 Ch 113 (CA).

144 At 117.

145 Harding, above n 62, at 168 referring to National Anti-Vivisection Society, above n 25, at 26-34 and 44-47.

146 At 168

147 At $168-169$.

148 At 169. 
Indeed, "there is to be no presumption that religion generally is for the public benefit", ${ }^{149}$ and that means that, for instance, there is no presumption that "Christianity or Islam are for the public benefit and no presumption that the Church of England is for the public benefit". 150

It is evident then that whilst the public benefit of religious purposes will have to be assessed in the United Kingdom, it is not clear how this will be undertaken and against what criteria.

Previously, the fundamental position in religious purpose cases has been that all religious charities should be treated equally and "the law of charity does not now favour one religion to another". ${ }^{151}$ Yet, the Charities Act 2006 (UK) means that value judgements may have to be made, but whose values and whose judgements? With such value judgements come an element of subjectivity, which in turn leads to uncertainty, and uncertainty was one issue that the removal of the presumption of public benefit sought to eradicate. The burden of proof now rests with the charity to establish the public benefit and that being so, this then suggests that such cases as Thornton and Watson may be decided differently if being judged in a contemporary context because on the evidence neither case "had much merit and their intrinsic value was minimal". 152

Further issues pertaining to public benefit may arise in relation to where the balance lies as to the benefit and harm of a set of religious beliefs as well as to whether certain doctrines amount to benefit or to harm, for instance, the prohibition of the use of modern technology. ${ }^{153}$ So whilst the Charities Act 2006 (UK) "raises the importance of public benefit", ${ }^{154}$ it also raises issues with regard to the requirement of proof of public benefit.

Perhaps then the removal of the presumption of public benefit is not necessarily the answer for New Zealand because in reality, whilst the presumption of public benefit can certainly be viewed as a nebulous and intangible concept, the concept of establishing public benefit for religious purposes is equally riddled with issues. Religious purposes are, generally, by their very nature, intangible and therefore presuming their benefit is a useful tool that relieves the courts of having to make potentially subjective judgement calls as to the moral and spiritual benefits of religious purposes. New Zealand has certainly gone some way to reaffirming the concept of the presumption in the case of Liberty Trust, and that should be welcomed, although this case presented as a double-edged sword. On the one hand, the case provided much needed certainty that the presumption of public benefit was still a very important consideration in the law of New Zealand. On the other, it has been

$149 R$ (Independent Schools Council), above n 26, at [84]

150 At [84].

151 Varsani v Jesani [1999] Ch 212 (CA) at 285 as cited in Smith, above n 47, at 72.

152 Smith, above n 47, at 72 .

153 Warburton, above n 22, at 14.

154 At 25 . 
argued that there was evidence to rebut the presumption, but this did not occur, suggesting then an overly broad interpretation of public benefit when there appeared to be sufficient evidence of private benefits that were not ancillary to the overall charitable purpose. Nonetheless, whilst the Liberty Trust decision does not satisfy the need for consistency and certainty in the application of the presumption of public benefit, it is useful because it affirms the value of the presumption as a tool in the judicial armoury regarding religious purposes, which is now perhaps lacking in the United Kingdom since the removal of this presumption.

\section{CONCLUSION}

"The concept of public benefit is intangible and nebulous; its effects can only be represented as variable and unpredictable, sometimes impossible to reconcile." 155 Unfortunately, even some five decades after this statement was made, "confusion still reigns in this area of law", ${ }^{156}$ and that certainly applies equally to the presumption of public benefit. As this article reflects, the United Kingdom has sought to provide certainty in this matter by removing the presumption of public benefit through the Charities Act 2006, and surely there is indeed a need for certainty and consistency. However, the removal of this presumption has not necessarily provided those hoped for benefits, at least with regard to the advancement of religion. Issues remain when the public benefit is related to spiritual enlightenment or spiritual development, where such benefits cannot be measured in any meaningful way. Indeed, the evaluation of such public benefit: ${ }^{157}$

... is not merely so impractical as to be effectively impossible ... but genuinely impossible: no advances

in technology or information-gathering will ever enable the meaningful evaluation of something

fundamentally incapable of evaluation.

It is clear that there have been, and continue to be, inherent difficulties with the presumption of public benefit. New Zealand has not sought to remove this presumption, although there will certainly be a review of the Charities Act 2005, and charitable purpose, which then raises the question as to whether New Zealand should follow in the footsteps of its commonwealth cousin. This article suggests that whilst New Zealand law also reflects judicial inconsistencies with the application of the presumption of public benefit, it is not clear that removing that presumption would be helpful. The author suggests that with the removal of the presumption of public benefit, it could be argued that this removed a useful tool by which the courts could evaluate public benefit. Public benefit and religion are inherently linked but with no meaningful method of evaluating that benefit, so perhaps presuming the public benefit is actually the most pragmatic method of approaching this issue. The contemporary New Zealand case of Liberty Trust reflects the Court's

155 Peter Luxton The Law of Charities (Oxford University Press, Oxford, 2001) at 171 as cited in Iwobi, above n 4 , at 631

156 Iwobi, above n 4, at 631.

157 Jonathan Garton Public Benefit in Charity Law (Oxford University Press, Oxford, 2001) at 110. 
desire to acknowledge that public benefit, even in the face of evidence that the benefit could have been rebutted. The public benefit of religion cannot be measured and this case reflects the reality of that.

Regardless of the growing atheist and secular movements, religion still remains the foundation of many contemporary societies and the inherent inability to judge the public value of religion surely suggests that the test of public benefit should be cast as widely as possible, or even simply presumed so as to reflect the realities of belief systems.

The courts' rejection of spiritual benefit both undermines the very nature of what it means to be religious and flies in the face of the importance, albeit archaic, attributed to spiritual matters elsewhere in charity law. 158

Therefore it is respectfully asserted that the removal of the presumption of public benefit is not the answer for New Zealand. Certainly there is a need for certainty and consistency when it comes to the consideration of public benefit and the advancement of religion, but it is not clear how removing that presumption really does assist a court when it comes to ascertaining the real public value, and thus benefit to a community, of the advancement of religion.

158 At 193 
